\title{
Effect of brain electrostimulation on antennal regeneration in Lithobius forficatus L. (Myriapoda : Chilopoda). Preliminary note
}

\author{
par R. JOLY $\left({ }^{1}\right)$, M. DESCAMPS $\left({ }^{2}\right)$
}

Service de Biologie animale

Université des Sciences ef Techniques de Lille, BP 36, 59655 Villeneuve d'Ascq Cedex, France.

Summary. After the antennae of Lithobius forficatus were amputated, electrical stimulation of the deutocerebral apex (= antennal lobes) either in the spring or the autumn led to (1) a decrease in the number of regenerated articles, and (2) an increase in the time-lag between the experiment and moulting. Moreover, in the spring experiments, the antennae regenerated asymmetrically.

The electrostimulatory effect could act through an endocrine centre, probably the cerebral glands.

\section{Introduction.}

In Myriapoda, antennal amputation leads to premature moulting (JuberthieJupeau, 1963 ; Seifert, 1966). In Lithobius forficatus (Joly and Lehovelleur, 1972), the increase in moulting percentages is directly related to the degree of amputation. Moulting seems to be triggered by a nervous factor whose action on a moulting inhibitory centre might be removed by antennectomy. This hypothesis has also been proposed in Arthropoda for Insecta (Urvoy, 1967) and some Crustacea Isopoda (Mocquard et al., 1971). Moreover, the physiological efficiency of electrical stimulation has been demonstrated by the fact that when applied to the frontal lobes or to the pars intercerebralis, it leads to physiological hyperactivity of these protocerebral endocrine areas, causing a decrease (frontal lobes) or an increase ( $\mathrm{pi}$ ) in the moulting rate and the metabolic activity during spermatocyte growth (Joly and Descomps, 197.7). This paper reports the effects of electrical deutocerebral stimulation on antennal regeneration in animals undergoing bilateral antennectomy. 


\section{Material and methods.}

Experiments were carried out on adult (maturus senior stage) L. forficatus males and females about 15 to 20 days after natural ecdysis, i.e., during the period of physiological rest in the moulting cycle (stage $C$ : Joly, 1966). Amputation was carried out between the first and the second article of the antenna. Electrical stimulation was given immediately after amputation by silver electrodes $(7 / 100 \mathrm{~mm}$ in diameter), set at the base of each antennal nerve (apex of the deutocerebral lobe). Rectangular electrical impulses $(200 \mu \mathrm{A}, 1 \mathrm{~ms}, 5 \mathrm{~Hz})$ were applied for either $10 \mathrm{~min}$ with the direction of the current reversed every $15 \mathrm{sec}$ or for $5 \mathrm{~min}$ without reversal. The parameters were continuously checked by an oscilloscope. These experimental conditions did not lead to nervous injuries but allowed the stimulation of a well-defined area (Joly and Descamps, 1977 ; Descamps, 1979). Animals undergoing only antennal amputation were used as controls.

Two main data were recorded : the number of regenerated articles, and the time-lag (in days) between amputation and moulting.

\section{Results.}

According to previous work (Joly and Lehovelleur, 1972), there is no difference between the moulting percentages in males and females after antennectomy ; similar results were obtained after electrical stimulation. Therefore, further results disregard the sex of the animals.

The moulting cycle in Lithobius forficatus males is not strictly related to the sexual cycle (Descamps, 1977). The experiments using females were performed during the autumn and the spring, the two main periods of egg-laying (Herbaut and Joly, 1972).

The moulting percentages after bilateral antennectomy were higher in the spring (93 p. 100) than in the autumn (72 p. 100) ; correlatively, the time-lag between antennectomy and moulting was shorter in the spring than in the autumn. After electrical stimulation, the percentage and the time-lag were 82 p. 100 and 41 days, respectively, in the spring and 70 p. 100 and 80 days in the autumn.

In these conditions, only the animals showing ecdysis before 60 days (spring) or before 120 days (autumn) after antennal section were considered.

Since the stimulation with or without reversing the direction of the current did not lead to significant differences, the total of all the stimulated animals was compared to the controls (table 1). The data were statistically analyzed using the t-test (Schwartz, 1963).

When we considered the fotal of the regenerated articles related to one antenna and compared the arithmetical means to those of the controls, we found that electrical stimulation led to a highly significant decrease in the number of regenerated antennal articles (spring experiments : ddl 100, $\dagger=5.67, \propto<0.001$; autumn experiments : ddl $108, t=5,62, \propto<0.001)$. 
TABLE 1

Effect of deutocerebral electrostimulation on antennal regeneration in L. forficatus

\begin{tabular}{|c|c|c|c|c|c|c|}
\hline & \multirow{2}{*}{$\begin{array}{c}\text { Total } \\
\text { number } \\
\text { of } \\
\text { animals }\end{array}$} & \multirow{2}{*}{$\begin{array}{c}\text { Number } \\
\text { of } \\
\text { moulting } \\
\text { animals }\end{array}$} & \multicolumn{3}{|c|}{$\begin{array}{l}\text { Number of regenerated articles } \\
\text { (arithmetical means } \pm S D \text { ) }\end{array}$} & \multirow{2}{*}{$\begin{array}{c}\text { Time-lag between } \\
\text { anfennectomy } \\
\text { and moulting } \\
\text { (arithmetical) } \\
\text { means in } \\
\text { days } \pm S D \text { ) }\end{array}$} \\
\hline & & & $\begin{array}{c}\text { right } \\
\text { antenna }\end{array}$ & $\begin{array}{c}\text { left } \\
\text { antenna }\end{array}$ & $\frac{\text { right }- \text { left }}{2}$ & \\
\hline \multicolumn{7}{|l|}{ Spring experiments } \\
\hline $\begin{array}{l}\text { Stimulated animals. } \\
\text { Controls } \ldots \ldots \ldots \ldots \\
\text { Autumn experiments }\end{array}$ & $\begin{array}{l}27 \\
31\end{array}$ & $\begin{array}{l}22 \\
29\end{array}$ & $\begin{array}{l}11.27 \pm 2.85 \\
13.66 \pm 2.26\end{array}$ & $\begin{array}{l}10.64 \pm 2.89 \\
13.69 \pm 1.71\end{array}$ & $\begin{array}{l}10.95 \pm 2.85 \\
13.67 \pm 1.99\end{array}$ & $\begin{array}{l}41.4 \pm \quad 6.1 \\
31.4 \pm 10.4\end{array}$ \\
\hline $\begin{array}{l}\text { Stimulated animals. } \\
\text { Controls ......... }\end{array}$ & $\begin{array}{l}53 \\
25\end{array}$ & $\begin{array}{l}37 \\
18\end{array}$ & $\begin{array}{l}11.19 \pm 2.70 \\
14.11 \pm 2.52\end{array}$ & $\begin{array}{l}10.14 \pm 3.13 \\
13.72 \pm 2.80\end{array}$ & $\begin{array}{l}10.66 \pm 2.95 \\
13.92 \pm 2.63\end{array}$ & $\begin{array}{l}80.8 \pm 27.7 \\
78.6 \pm 30.5\end{array}$ \\
\hline
\end{tabular}

Nevertheless, there were quantitative variations between the two antennae of the same animal. These variations seemed to be less in the controls. So, the differences in the number of regenerated articles of the two antennae were compared in stimulated and control animals. In the spring experiments, the difference was significant (ddl 49, $\mathrm{t}=2.03,0.02<\propto<0.05$ ) and in the autumn experiments it was not significant (ddl 53, $t=1.46,0.10<\propto<0.20$ ).

As compared to the controls, the time-lag between antennectomy and moulting was significantly different in the spring (ddl 49, $\mathrm{d}=4.00, \propto<0.001$ ) but not in the autumn (ddI 53, $t=0.26,0.50<\propto<0.90$ ).

\section{Discussion.}

Electrostimulation of the apex of the deutocerebral lobes, performed after antennectomy, led to a decrease in the number of regenerated articles and to an increase in the time-lag between antennectomy and moulting, i.e., moulting cycle duration, since the experiments were performed during the period of physiological rest in the cycle. This increase was particularly marked in the spring experiments.

The effect of electrical stimulation could act through an endocrine centre. Indeed, the cerebral glands (paired cephalic endocrine organs) exert a moderating action on the moulting cycle (Joly, 1961), and when studied ultrastructurally after deutocerebral stimulation, they reveal an increase in the secretory activity (fig. 1).

The asymmetry noted in the antennal regenerates could result from perturbation of regeneration due to a change in moulting cycle duration, a change greater in the spring than in the autumn. 
FIG. 1. - Ultrastructural study of the cerebral gland in L. forficatus.

a) After deutocerebral lobe electrostimulation, secretory activity persists in the Golgi apparatus 27 days affer ecdysis. $\times 25300$.

b) With no electrostimulation, the secretory activity stops about 20 days after ecdysis (cf. Joly, 1970). $\times 25300$.

e : ergastoplasm ; $G$ : Golgi apparatus ; $S$ : granule of secretion ; v : vacuoles with flocculent secretion. Scale bar : $1 \mu \mathrm{m}$. 


Résumé. Pratiquée après antennectomie bilatérale, l'électrostimulation des lobes antennaires de $L$. forficatus entraîne, quelle que soit la saison de l'intervention (printemps ou automne) :

1) une diminution du nombre des articles régénérés ;

2) une augmentation du laps de temps séparant l'opération de la mue.

De plus, on constate une régénération antennaire significativement asymétrique, lorsque les opérations sont réalisées au printemps.

L'effet de l'électrostimulation pourrait s'exercer par l'intermédiaire des glandes cérébrales, organes endocrines céphaliques.

\section{References}

DESCAMPS M., 1977. Influence de la croissance somatique sur le cycle spermatogénétique de Lithobius forficatus L. (Myriapode Chilopode). Gen. comp. Endocr., 33, 412-422.

DESCAMPS M., 1979. Influence of the ventral nerve cord on the spermatogenetic cycle in Lithobius forficatus L. (Myriapoda, Chilopoda). Int. J. Invert. Reprod., 1, 205-208.

HERBAUT C., JOLY R., 1972. Activité ovarienne et cycle ovogénétique chez Lithobius forficatus L. (Myriapode Chilopode). Arch. Zool. exp. gén., 113, 215-225.

JOLY R., 1961. Déclenchement expérimental de la mue chez Lithobius forficatus L. (Myriapode Chilopode). C. R. Acad. Sci. Paris, 252, 1673-1675.

JOLY R., 1966. Etude expérimentale du cycle de mue et de sa régulation endocrine chez les Myriapodes Chilopodes. Gen. comp. Endocr., 6, 519-533.

JOLY R., 1970. Evolution cyclique des glandes cérébrales au cours de l'intermue chez Lithobius forficatus L. (Myriapode Chilopode). Z. Zellforsch., 110, 85-96.

JOLY R., DESCAMPS M., 1977. Influence de l'électrostimulation cérébrale sur l'histologie ultrastructurale et le rôle physiologique des glandes cérébrales chez Lithobius forficatus L. (Myriapode Chilopode). Arch. Biol., 88, 333-347.

JOLY R., LEHOUELLEUR J., 1972. Effet de la section antennaire sur le déclenchement de la mue chez Lithobius forficatus L. (Myriapode Chilopode). Gen. comp. Endocr., 19, 320-324.

JUBERTHIE-JUPEAU L., 1963. Influence de l'ablation des antennes sur la durée de l'intermue et sur le cycle de spermatogenèse chez les Symphyles. Gen. comp. Endocr., 3, 710.

MOCQUARD J.-P., BESSE G., JUCHAULT P., LEGRAND J.-J., MAISSIAT J., NOULIN G., 1971. Contribution à l'analyse du contrôle neurohumoral de la croissance, de la mue et de la physiologie sexuelle mâle et femelle chez l'Oniscoïde Ligia oceanica L. (Crustacé Isopode). Ann. Embryol. Morphol., 4, 45-63.

SCHWARTZ D., 1963. Méthodes statistiques à l'usage des médecins et des biologistes. Ed. Médic. Flammarion, Paris.

SEIFERT G., 1966. Häutung verursachende Reize bei Polyxenus lagurus L. (Diplopoda, Pselaphognatha). Zool. Anz., 177, 258-263.

URVOY J., 1967. Etude de l'influence du système nerveux central sur la reconstitution d'appendices après ablation tofale ou partielle de ceux-ci chez Blabera craniifer L. Bull. Soc. Zool. Fr., 92, 409-417. 